\title{
Wyspa wolności?
}

\section{Zgromadzenia Izby Adwokackiej w Łodzi w latach 1962-1968}

\section{Streszczenie}

W artykule przedstawiono funkcjonowanie samorządu adwokackiego w okresie Polskiej Rzeczypospolitej Ludowej na przykładzie zgromadzeń łódzkiej Izby Adwokackiej odbywających się w latach 60. Zachowane protokoły tych zgromadzeń poddano analizie w poszukiwaniu odpowiedzi na pytanie, czy - a jeżeli tak, to w jakim zakresie - możliwe były wystąpienia krytyczne wobec działań socjalistycznej władzy. Autor stawia tezę, że podczas dyskusji łódzkich adwokatów pojawiały się także wypowiedzi wyraźnie kontestujące konkretne działania administracji państwowej; w szczególności dotyczyły one sprawy adw. Karola Głogowskiego, wykluczonego z palestry za działalność opozycyjną. Nie może jednak dziwić, że nie odnotowano głosów sprzeciwu wobec ustroju socjalistycznego jako takiego - margines swobody istniał, ale nie był aż tak szeroki.

Słowa kluczowe: samorząd adwokacki, Okręgowa Izba Adwokacka w Łodzi, Karol Głogowski.

\section{Uwagi wstępne}

W Polsce Ludowej adwokaturze pozostawiono pewne elementy samorządu. Oczywiście, w państwie zorganizowanym zgodnie z zasadami „centralizmu demokratycznego" oraz przewodniej roli monopartii (w 1976 r. wpisanej do ustawy zasadniczej) nie było miejsca na niezależność palestry, która podlegać miała silnemu nadzorowi ze strony administracji rządowej i struktur partii robotniczej. Ludowa władza traktowała adwokatów jako element niepewny, $\mathrm{z}$ rezerwą podchodzący do socjalistycznej rzeczywistości. Działania podjęte w latach 40. pozwoliły podporządkować palestrę aparatowi PPR (a później PZPR), a domknięciem tego procesu stała się ustawa z 27 czerwca 1950 r. o ustroju adwokatury¹. Na mocy jej przepisów

1 Dz.U. Nr 30 poz. 275. 
utrzymano strukturę izb adwokackich, nazywanych odtąd wojewódzkimi. Ich liczbę zwiększono z dziewięciu do siedemnastu, dostosowując strukturę do podziału administracyjnego państwa. Organami izb miały być walne zgromadzenia, rady adwokackie oraz komisje rewizyjne. W ustawie z $1950 \mathrm{r}$. nie przewidziano zwoływania zjazdu adwokatury, a w skład Naczelnej Rady Adwokackiej wchodzili dziekani rad adwokackich wraz z siedmioma przybranymi przez nich adwokatami mającymi siedzibę w Warszawie (art. 35). Zgodnie z art. 18 pkt 1 ustawy członkowie rad adwokackich byli wybierani przez walne zgromadzenia, w których - jak stanowił art. 17 ust. 1 - mogli uczestniczyć wszyscy członkowie izb ${ }^{2}$.

Kolejną ustawę ustrojową uchwalono 13 lat później ${ }^{3}$ Wyraźnie wskazano w niej, że do zadań samorządu adwokackiego należy „zapewnienie właściwej postawy społecznej" adwokatury (art. 1 ust. 2), a pomoc prawna nadal miała być udzielana zgodnie z „interesem mas pracujących” (art. 2). Coroczne zebranie delegatów wojewódzkiej izby adwokackiej wybierało członków wojewódzkiej rady adwokackiej, komisji rewizyjnej oraz komisji dyscyplinarnej (art. 37, art. 40 i art. 41); dziekan izby był natomiast wybierany przez radę wojewódzką (art. 47). Samorząd poddany został nadzorowi ze strony ministra sprawiedliwości. Mógł on rozwiązać radę, której „działanie lub zaniechanie narusza prawo lub zagraża interesowi społecznemu” (art. 47 ust. 1).

Postanowiliśmy poszukać odpowiedzi na pytanie, czy podczas corocznych zebrań adwokatów miały okazję ujawnić się nastroje opozycyjne wobec władz, czy też spotkania owe były w takim stopniu poddane partyjnemu nadzorowi, że głosy krytyczne nie mogły wybrzmieć. Warto przy tym rozważyć, czy ewentualne wypowiedzi kontestujące rzeczywistość dotyczyły tylko konkretnych problemów lub decyzji organów państwowych, czy można wśród nich odnaleźć i takie, które stanowily negatywną ocenę socjalistycznego ustroju lub niedemokratycznego systemu rządów.

Badania ograniczyliśmy do lat 60. XX w., czyli do okresu siermiężnej gomułkowskiej stabilizacji, aż do ujawnienia się w kraju nastrojów opozycyjnych w 1968 r. Wstępnie założyć można, że w tym czasie ostrzejsza krytyka socjalistycznej władzy była szczególnie mało prawdopodobna. Sięgnęliśmy do protokołów ze zgromadzeń delegatów Wojewódzkiej Izby Adwokackiej w Łodzi, które zachowały się w archiwum łódzkiej Izby Adwokackiej. Nie jest to kolekcja kompletna, udało się bowiem odszukać jedynie protokoły zgromadzeń z 1965, 1966 i 1968 r. (opatrzone podpisami, czyli najprawdopodobniej przyjęte) oraz projekty

2 A. Redzik, T.J. Kotliński, Historia adwokatury, Warszawa 2012, s. 300-316 (w pracy tej znalazła się błędna informacja, iż członkowie NRA powoływani byli przez ministra sprawiedliwości); M. Zaborski, Cuius regio, eius palestra? Na drodze do adwokatury państwa totalitarnego. Przemiany ustrojowe adwokatury polskiej w latach 1944-1963, [w:] Cuius regio, eius religio. Publikacja po Zjeździe Historyków Państwa i Prawa, Lublin, wrzesień 2006, t. II, red. G. Górski, L. Ćwikła, M. Lipska, Lublin 2008, s. 427-456. 
(stenogramy) protokołów z lat 1962 i 1967 (ten drugi urwany, bez końcowej części ${ }^{4}$. Ostatnie dwa dokumenty również uwzględniliśmy w badaniach, zakładając, że brak zatwierdzenia i podpisania nie zmniejsza istotnie ich przydatności jako źródła informacji o przebiegu zgromadzeń ${ }^{5}$. Zebrana próba nie jest imponująca, jednak okazała się wystarczająca do poczynienia interesujących ustaleń i sformułowania na ich podstawie wniosków.

\section{2. Łódzka Izba Adwokacka i jej zgromadzenia do 1968 r.}

Izba Adwokacka w Łodzi powstała w grudniu 1949 r. wraz z utworzeniem w tym mieście Sądu Apelacyjnego. Wcześniej działała tam jedynie Delegatura Izby Adwokackiej w Warszawie. Pierwszym łódzkim dziekanem został Eugeniusz Pieńkowski, mianowany przez ministra sprawiedliwości. Na koniec 1951 r. Izba liczyła 290 adwokatów i 60 aplikantów. Po wejściu w życie „ludowej” ustawy o adwokaturze 1 lutego 1951 r. minister sprawiedliwości powołał Wojewódzką Radę Adwokacką. Kierowanie nią powierzył Kazimierzowi Aspisowi-Popeckiemu, który okazał się w znacznie większym stopniu stalinowskim nadzorcą nad łódzką palestrą niż jej samorządowym działaczem. W maju 1953 r. zastąpił go Mieczysław Olczyk, a od maja 1956 r. funkcję dziekana pełnił Zygmunt Albrecht, który Izbą kierował aż do maja 1973 r. $^{6}$

4 Stenogram. Walne Zgromadzenie Adwokackiej Izby Łódzkiej. Łódź, dnia 16 grudnia 1962 r., w teczce: Walne Zgromadzenie Delegatów r. 1962. Mec. W. Osuchowski. Stenogram 1962, sygn. 7/13 [dalej: Protokół 1962]; Protokół ze Zgromadzenia Delegatów Łódzkiej Izby Adwokackiej odbytego w dniu 11 kwietnia 1965 r. w lokalu własnym przy ul. Piotrkowskiej 63, w teczce: Protokół Zebrania Delegatów r. 1965, sygn. 7/16 [dalej: Protokół 1965]; Protokół ze Zgromadzenia Delegatów Łódzkiej Wojewódzkiej Izby Adwokackiej odbytego w dniu 17 kwietnia 1966 r. w lokalu własnym przy ul. Piotrkowskiej 63, w teczce: Protokót ze Zgromadzenia Delegatów Łódzkiej Wojewódzkiej Izby Adwokackiej 17 IV 1966 r., sygn. 7/18 [dalej: Protokół 1966]; Protokół Zgromadzenia Delegatów Wojewódzkiej Izby Adwokackiej w Łodzi z dnia 16 kwietnia 1967 r., w teczce: Protokót zgromadzenia delegatów Wojewódzkiej Izby Adwokackiej w Łodzi 1967, sygn. 7/21 [dalej: Protokół 1967]; Protokół Zgromadzenia Delegatów Wojewódzkiej Izby Adwokackiej w Łodzi w dniu 6 IV 1968 r., w teczce: Zgromadzenie Delegatów Izby Adwokackiej w Łodzi w dniu 6 IV 1968, sygn. 7/23 [dalej: Protokót 1968]. W 1961 r. zgromadzenie odbyło się 19 marca, protokół nie zachował się; jedynie na łamach „Palestry” opublikowano obszerne fragmenty wystąpienia dziekańskiego - zob. przypis 42.

5 Wszak przyjęcie i podpisanie protokołu nie daje gwarancji, że jego treść jest całkowicie zgodna z przebiegiem zebrania.

660 Lat Łódzkiej Izby Adwokackiej, Łódź 2009, s. 18-21. 
O zgromadzeniach łódzkiej Izby w latach 60 . wiemy tyle tylko, ile udało się ustalić na podstawie zachowanych protokołów. Nie mamy nawet pewności, czy spotkania odbywały się corocznie, przyjmujemy jednak, że tak było. Zgodnie z przepisami ustawy z $1963 \mathrm{r}$. zgromadzenia nie były zebraniami wszystkich członków Izby, ale udział w nich brali delegaci wybrani w zespołach adwokackich. W teczkach z dokumentacją kolejnych zgromadzeń znajdują się protokoły z zebrań wyborczych odbywających się w poszczególnych zespołach, ich analiza wykraczałaby jednak poza ramy opracowania.

Z zestawienia przygotowanego dla Naczelnej Rady Adwokackiej w 1966 r. wynikało, że wybrano wówczas 102 delegatów, z których 97 obecnych było na zgromadzeniu. Wśród wybranych było 78 członków zespołów adwokackich, 23 radców prawnych i 1 rencista. Co ciekawe, analizowano także przynależność partyjną delegatów: w ich gronie było 11 członków PZPR, 8 SD i 5 ZSL, pozostałych 78 było bezpartyjnych ${ }^{7}$.

Zgromadzenia odbywały się w różnych miejscach - w 1964 r. w budynku łódzkiego Sądu Wojewódzkiego, a w 1965 i 1966 r. w lokalu Izby Adwokackiej przy ul. Piotrkowskiej $63 \mathrm{w}$ Łodzi ${ }^{8}$.

Od 1964 r. zasady obradowania określał regulamin zgromadzeń delegatów w wojewódzkich izbach adwokackich uchwalony przez Naczelną Radę Adwokacką w dniu 29 lutego 1964 r., zatwierdzony przez ministra sprawiedliwości decyzją z dnia 13 marca $1964 \mathrm{r}^{9}{ }^{9} \mathrm{~W}$ jego $\$ 33$ zagwarantowano udział „,czynników partyjno-państwowych” $\mathrm{w}$ samorządowych wyborach. W przywołanym przepisie zapisano, że kandydatury do organów izby zgłaszał Komitet Frontu Jedności Narodu utworzony w tym celu spośród adwokatów danej izby. Na liście miało znaleźć się tyle nazwisk, ile osób wybierano do danego organu (ust. 1). Dopuszczono zgłaszanie innych kandydatów, jednak ich liczba nie mogła przekroczyć $50 \%$ liczby kandydatów z listy Frontu (ust. 2). W ten sposób zapewniono, że przynajmniej połowa członków każdego z organów pochodzić będzie z grupy zaakceptowanej przez czynniki oficjalne ${ }^{10}$.

7 [Pismo sekretarza ORA Stefana Majsterka do Naczelnej Rady Adwokackiej z dnia 7 czerwca 1966 r.], w teczce: Protokół ze Zgromadzenia [...] 17 IV 1966 r.

8 Protokót 1964, s. 1; Protokół 1965, s. 1; Protokół 1966, s. 1.

9 Egzemplarz regulaminu w teczce: Protokół ze Zgromadzenia [...] 17 IV 1966 r.

10 Wykonując tę dyspozycję, Okręgowa Rada Adwokacka pismami datowanym na 29 kwietnia 1964 r. o powołanie takiego komitetu zwróciła się do Wojewódzkiego oraz Łódzkiego Komitetu FJN - oba pisma w teczce: Protokół Zebrania Delegatów r. 1965; zob. też: Protokół 1967, s. 27. 


\section{Udział przedstawicieli władz państwowych i partyjnych}

W zgromadzeniach Izby jako goście brali udział nie tylko przedstawiciele Naczelnej Rady Adwokackiej oraz łódzkich sądów i prokuratur, ale także reprezentanci władz partyjnych i państwowych. Stałym przedstawicielem Ministerstwa Sprawiedliwości był wiceminister ${ }^{11}$ Kazimierz Zawadzki ze Stronnictwa Demokratycznego, którego obecność odnotowano w protokołach z lat: 1965, 1966 i 1968. Zabierał wówczas głos, a kilka jego wypowiedzi miało wymiar wręcz symboliczny. W 1965 r. przekonywał, że „wydziały rewizyjne Sądów Wojewódzkich nie pracują jeszcze najlepiej. Zbyt dużo jest wyroków uchylających i uniewinniających"12. Natomiast w 1968 r., krótko po wydarzeniach marcowych, dość jasno wyraził swoją - a raczej urzędową - ich ocenę: „winno się dać wyraz stosunkowi do tych niespokojnych i burzliwych czasów, w których podniosły się głowy różnych wrogów naszego kraju i naszego ustroju"13.

W 1965 r. na zgromadzeniu obecni byli reprezentanci komitetu wojewódzkiego i łódzkiego PZPR - Aleksander Hempel i Jan Wilczak ${ }^{14}$. Rok później w protokole odnotowano obecność większej liczby gości, którymi byli: przedstawiciel Wydziału Administracyjnego KC PZPR Jan Syty, kierownik Wydziału Administracyjnego KW Stanisław Pietruszka, przedstawiciel Komitetu Łódzkiego J. Wilczak oraz doc. dr Mikołaj Leonieni reprezentujący Komitet Miejski Stronnictwa Demokratycznego. W prezydium zgromadzenia zasiadł wówczas J. Syty wraz z wiceministrem Zawadzkim ${ }^{15}$.

W 1967 r. przybyli przedstawiciele kierownictwa PZPR na szczeblu centralnym („przedstawiciel Wydziału Administracyjnego KC PZPR tow. J. Syty”) oraz lokalnym (kierownik Wydziału Administracyjnego Komitetu Łódzkiego Tadeusz Jabłczyński), a także reprezentanci ugrupowań satelickich: ZSL („ob. Paterka”) oraz SD („ob. Romuald Szyburski i ob. Ryszard Świątecki”) ${ }^{16}$.

Również w 1968 r. na początku obrad powitano gości reprezentujących PZPR, w tym kierownika Wydziału Administracyjnego Komitetu Łódzkiego, a także pierwszego sekretarza POP (czyli podstawowej organizacji partyjnej) Eugeniusza Sindlewskiego ${ }^{17}$.

11 W protokołach nazywany „Ministrem Sprawiedliwości”.

12 Protokół 1965, s. 11.

13 Protokót 1968, s. 6.

14 Protokót 1965, s. 1.

15 Protokót 1966, s. 1-2.

16 Protokót 1967, s. 1.

17 Protokót 1968, s. 1. 
Świetną ilustracją podejścia władz partyjnych do palestry wydaje się wystąpienie reprezentującego Komitet Wojewódzki PZPR St. Pietruszki, który w 1966 r. powiedział m.in.:

adwokat $[\ldots]$ nie może stać na uboczu następujących przemian społecznych, a ma obowiązek brać udział w przebudowie stosunków międzyludzkich na stosunki socjalistyczne [...], do obowiązków adwokatury należy również wypracowanie nowych form walki z pieniactwem oraz zapobieganie przewlekłości sporu. Adwokat w nowym ujęciu jest filarem sprawiedliwości, a zatem nie powinien reprezentować też błędnych poglądów ${ }^{18}$.

\section{Dyskusje o funkcjonowaniu Izby i jej członków oraz wymiaru sprawiedliwości}

Podczas zgromadzeń łódzkich adwokatów dyskutowano przede wszystkim o różnych problemach związanych z wykonywaniem zawodu. Z protokołów wyłania się obraz środowiska niezbyt zamożnego, choć jednocześnie zróżnicowanego pod względem statusu materialnego. W 1962 r. Kazimierz Jocz użył nawet pojęcia „biedota adwokacka”, odnosząc je do adwokatów pracujących w biurach doraźnej pomocy prawnej ${ }^{19}$. Podczas tego samego zgromadzenia dziekan Albrecht wskazywał, że zwiększonym obrotom członków Izby towarzyszą niższe zarobki; przekonywał przy tym, że rozwiązaniem powinno być zmniejszenie liczby adwokatów w Izbie (co - jego zdaniem - miało nastąpić „drogą naturalną, gdyż adwokatura jest stara") ${ }^{20}$. Mówiono też o trudnej sytuacji finansowej obrońców, ich pauperyzacji oraz o kominach płacowych w zespołach ${ }^{21}$. Pobocznym wątkiem w dyskusji okazały się problemy taksy adwokackiej i dochody adwokatów-rencistów ${ }^{22}$.

W wypowiedziach dotyczących zróżnicowania zarobków adwokatów łatwo dostrzec wpływ socjalistycznego myślenia o gospodarce i płacach. Dziekan Albrecht wskazywał na konieczność podnoszenia minimalnego udziału w dochodach ${ }^{23}$ i niwelowania różnic w zarobkach ${ }^{24}$. Adwokat R. Kowalski przekonywał, że „jest dużo

18 Protokót 1965, s. 8-9.

19 Protokół 1962, s. 54. Trzy lata później Bronisław Appel ubolewał nad „pauperyzacją zawodu” - Protokót 1965, s. 9.

20 Protokót 1962, s. 13.

21 Protokót 1965, s. 8-9; Protokół 1966, s. 7.

22 Protokót 1968, s. 13.

23 Protokót 1967, s. 4.

24 Protokót 1968, s. 3. 
kolegów zarabiających skromnie i należy ich potrzeby zaspokoic”, zaś „problem leży w rozdziale spraw i klientów" ${ }^{25}$. W innym duchu przemawiał Tadeusz Grabowski, zdaniem którego „wolny wybór adwokata przez klienta to fikcja, grupa adwokatów ma monopol do występowania na sali numer 1", czyli głównej sali ówczesnego sądu wojewódzkiego ${ }^{26}$.

Adwokaci wypowiadali się na temat kwestii socjalnych - zwrotu kosztów leczenia w szpitalach, wypłacania przez wojewódzką radę zasiłków chorobowych, zasiłków stałych dla adwokatów oraz wdów po adwokatach, pożyczek z funduszu pomocowego oraz utworzenia stałego ambulatorium lekarskiego w siedzibie rady ${ }^{27}$. Mówiono o adwokackim ośrodku wypoczynkowym w podłódzkich Grotnikach (który do dzisiaj pozostaje przedmiotem dyskusji podczas zgromadzeń łódzkich adwokatów) $)^{28}$, pojawił się też postulat utworzenia „ośrodka wypoczynkowego w atrakcyjnej miejscowości" 29.

Wspominano także o sytuacji zespołów adwokackich, w szczególności o warunkach panujących w ich siedzibach ${ }^{30}$. W 1967 r. Z. Albrecht przypomniał, że zespoły w Wieruszowie i Sieradzu doczekały się „luksusowych nowoczesnych lokali”31. Niezbyt wiele uwagi poświęcono aplikantom. W 1965 r. wiceminister Zawadzki przekonywał, że „w obecnej sytuacji nie trzeba większej ilości adwokatów, dlatego niepotrzebny jest nabór większej ilości aplikantów”32.

Zabierający głos adwokaci wskazywali na trudności w wykonywaniu zawodu. Zwracano uwagę na brak pokoi adwokackich w sądach ${ }^{33}$ i zgłaszano szczegółowe wnioski dotyczące funkcjonowania sekretariatów w sądach i prokuraturach ${ }^{34}$. Znamienny może być głos Józefa Rodziewicza, który narzekał, że adwokaci marnują czas w sądach, i postulował, by umożliwić uzyskanie informacji przez telefon w sekretariatach wydziałów ${ }^{35}$. Z kolei dziekan Albrecht domagał się, by w tychże sekretariatach adwokaci byli obsługiwani bez kolejki ${ }^{36}$. Nietrudno dostrzec, że niektóre problemy pozostały nierozwiązane do dzisiaj.

W 1966 r. Irena Dogiel-Pionkowska zwracała uwagę na konieczność budowy nowego skrzydła w budynku sądu wojewódzkiego na pl. Dąbrowskiego ${ }^{37}$. Dwa lata później wiceminister Zawadzki zapewniał, że nowy gmach sądu jest

25 Protokót 1967, s. 21-22.

26 Tamże, s. 23.

27 Protokót 1962, s. 11-14; Protokót 1967, s. 40.

28 Protokót 1962, s. 8-9; Protokót 1967, s. 19.

29 Protokót 1967, s. 40.

30 Protokót 1966, s. 4.

31 Protokót 1965, s. 18.

32 Tamże, s. 10.

33 Protokót 1968, s. 4.

34 Protokót 1966, s. 5; Protokół 1967, s. 40.

35 Protokót 1967, s. 31.

36 Protokót 1968, s. 4.

37 Protokót 1966, s. 8. 
„W zakresie zainteresowań ministerstwa”. Rzeczywiście - już 44 lata później został oddany do użytku ${ }^{38}$.

Przywołana wyżej adw. Dogiel-Pionkowska odnosiła się także do zasad wyznaczania tzw. urzędówek, czyli delegowania do zastępstwa z urzędu w sprawach sądowych ${ }^{39}$. Warto przy tym zauważyć, że w mieście włókniarek problem ten nie był tak istotny, jak w niektórych innych ośrodkach. Zgodnie z informacjami przekazanymi zebranym przez wiceprezesa NRA Tadeusza Gierzyńskiego - w Łodzi tzw. urzędówki stanowiły tylko $4 \%$ spraw, podczas gdy w Szczecinie $29 \%$, a w Koszalinie $24 \%{ }^{40}$.

\section{Zgodnie z linią partii}

Podczas zgromadzeń zdarzały się i takie wypowiedzi, które świetnie wpisywały się w klimat partyjnej nowomowy. Trzeba je przypomnieć dla wykazania, że wystąpienia zawierające elementy krytyki władzy nie były ani jedyne, ani oczywiste.

W przemówieniu z 4 kwietnia 1968 r., wygłoszonym bezpośrednio po wydarzeniach marcowych, dziekan Albrecht pozytywnie oceniał współpracę partii z palestrą. Mówił o „dobrych stosunkach z instytucjami politycznymi” i ich pomocy w staraniach o lokale dla zespołów adwokackich; wskazał też, że „okres kampanii wyborczej kierowników zespołów jeszcze bardziej zbliżył nas do instancji partyjnych" ${ }^{41}$. Siedem lat wcześniej ten sam dziekan jasno przedstawił swe poglądy na relacje adwokatury $\mathrm{z}$ władzą ludową:

Gdy w takich sytuacjach jak dzisiejsza mamy sposobność i obowiązek zastanowienia się nad własnymi, a nie - jak zwykle - cudzymi sprawami, myślę, że możemy także żywić nadzieję, iż Partia i Minister Sprawiedliwości, a więc czynniki, wobec których żywimy lojalność i posłuch nie ze strachu, lecz z głębokiego przekonania, rozważą zagadnienia dotyczące naszego zawodu w sposób sprawiedliwy dla ogółu adwokatury i pożyteczny dla społeczeństwa ${ }^{42}$.

Rolę samorządu adwokackiego - „ze słusznych pozycji” - przedstawiał Andrzej Jaklicz (będący wówczas przewodniczącym Frontu Jedności Narodu w dzielnicy Łódź-Śródmieście): „partia, jako kierownik klasy robotniczej, uznała za odpowiadające prawidłowości rozwoju społeczeństwa w Polsce Ludowej wyposażenie

38 Protokót 1968, s. 6.

39 Protokół 1966, s. 8; podobnie rok wcześniej Z. Albrecht - Protokół 1965, s. 11.

40 Protokót 1968, s. 12-13.

41 Tamże, s. 4.

42 Z. Albrecht, Przemówienie na Walnym Zgromadzeniu Izby łódzkiej w dniu 19 marca 1961 r. (fragmenty), „Palestra” 1961, nr 5(41), s. 9. 
adwokatury w samorząd"43. Organy palestry miały zatem - jego zdaniem - działać na podstawie i w granicach koncesji udzielonej przez kierownictwo partyjne.

Partyjni adwokaci podkreślali znaczenie podstawowej organizacji partyjnej w życiu palestry. W 1962 r. Mieczysław Błochowicz tłumaczył, że POP nie jest instancją nadrzędną nad Radą i dodawał: „jesteśmy tylko doradcą w kwestiach politycznych”. Tłumaczył przy tym, na czym polega szczególna rola adwokatów należących do PZPR: „każdy członek partii jest jednocześnie adwokatem, [ale] tylko my, mówiąc o interesie adwokatury, rozumiemy go szerzej niż przeciętny adwokat, który będzie [...] na każdym kroku [...] mówił o taksie i o podatku od wynagrodzeń"44. Mieczysław Korczak nawoływał do „socjalizacji adwokatury” i postulował, by komórka partyjna miała wpływ na decyzje o wpisaniu na listę adwokatów ${ }^{45}$. W 1967 r. ten sam adwokat przekonywał, że „dzielenie adwokatów na ZSL-ów, partyjnych i bezpartyjnych ma służyć pewnemu celowi, którym jest wygranie niektórych atutów stanowiących w pewnym sensie argument polityczny" ${ }^{46}$.

Ze sprawozdania z działalności rady adwokackiej dowiadujemy się, że 12 października 1968 r. odbyła się „narada licznego aktywu izby poświęcona omówieniu aktualnej problematyki politycznej”, a także że „wzrosła aktywność społeczna adwokatów, co jest wynikiem ogromnego ożywienia społeczno-politycznego przed V Zjazdem PZPR”. Co ciekawe, adwokaci brali również udział w „masowym szkoleniu rolniczym”47 (nie dowiedzieliśmy się jednak, jakie pożyteczne umiejętności udało się im zdobyć).

Stopień „politycznego uświadomienia” łódzkiej palestry nie był szczególnie wysoki, nad czym ubolewali zwolennicy nowego ustroju. W 1962 r. M. Błochowicz wskazywał, że jedynie kilkunastu adwokatów uczestniczyło w obchodach rocznicy rewolucji październikowej, A. Jaklicz zaś martwił się, że w dzielnicy Śródmieście tylko kilku adwokatów jest zaangażowanych w „budownictwo socjalistyczne” ${ }^{48}$.

\section{Sprawa Karola Głogowskiego}

Podczas omawianych zgromadzeń łódzkiej Izby Adwokackiej zdecydowanie najciekawsze były wystąpienia związane ze sprawą Karola Głogowskiego. Stanowią one swoisty papierek lakmusowy pozwalający na stwierdzenie, czy uczestnicy

43 Protokót 1962, s. 94.

44 Tamże, s. 82-85.

45 Protokół 1966, s. 13.

46 Protokót 1967, s. 25.

47 Sprawozdanie Okręgowej Rady Adwokackiej za 1968 r., w teczce: Walne Zgromadzenie Delegatów Wojewódzkiej Izby Adwokackiej w Łodzi w dniu 16 IV 1967, sygn. 7/22.

48 Protokót 1962, s. 82, 93. 
obrad mogli pozwolić sobie na krytykę decyzji władzy ludowej i czy w dyskusji miały szansę ujawnić się nastroje opozycyjne.

Omawianie tzw. sprawy Głogowskiego poprzedzić należy zarysowaniem sylwetki jej bohatera oraz przywołaniem wydarzeń, na temat których dyskutowano. Karol Głogowski (1933-2005) od 1957 r. był adwokatem w Zespole Adwokackim nr 1 w Łodzi. Stał się jednym z przywódców Związku Młodych Demokratów, założonego jesienią 1956 r. na fali październikowej odwilży. Była to organizacja prodemokratyczna i niepodległościowa, od $1957 \mathrm{r}$. działająca w konspiracji. W marcu 1964 r. Głogowski został zatrzymany w trakcie spotkania grupy opozycjonistów, a podczas przeszukania jego mieszkania znaleziono nielegalne publikacje oraz recenzję książki Mieczysława Zawistowskiego Sprawy Polskie. Został wówczas aresztowany $\mathrm{w}$ związku z zarzutem popełnienia przestępstwa $\mathrm{z}$ art. $23 \$ 1$ małego kodeksu karnego ${ }^{49}$, które miało polegać na przechowywaniu i rozpowszechnianiu opracowania, „które fałszywie i ze szkodą dla interesów Państwa Polskiego charakteryzuje stosunki społeczno-polityczne i ekonomiczne Polski Ludowej, a nadto podważa słuszność współpracy polityczno-gospodarczej Polskiej Rzeczypospolitej Ludowej ze Związkiem Radzieckim"50.

W lipcu 1964 r. wiceminister sprawiedliwości Kazimierz Zawadzki wydał decyzję o zawieszeniu K. Głogowskiego w wykonywaniu zawodu adwokata. Postanowieniem z 13 sierpnia 1964 r. Sąd Powiatowy dla m. Łodzi odstąpił od stosowania tymczasowego aresztowania, a wyrokiem z 29 września 1964 r. Głogowski został uniewinniony. W wyniku rewizji 5 marca 1965 r. Sąd Wojewódzki w Łodzi zmienił wyrok uniewinniający, ale przyjął inną, względniejszą, kwalifikację czynu i umorzył postępowanie na podstawie przepisów o amnestii; nie był to jednak koniec sprawy. Wcześniej, 15 października 1964 r., uchylono decyzję o zawieszeniu w wykonywaniu zawodu, ale 15 lutego 1965 r. Głogowski został zawieszony ponownie, co uzasadniono wniesieniem rewizji na jego niekorzyść. Mimo umorzenia postępowania przez sąd drugiej instancji decyzja o zawieszeniu nie została uchylona, a młody adwokat zmuszony był utrzymywać się z datków kolegów z palestry. W sierpniu 1965 r. Sąd Najwyższy, uwzględniając rewizję nadzwyczajną ministra sprawiedliwości, uchylił wyroki sądów niższych instancji i przekazał sprawę do rozpoznania Sądowi Powiatowemu dla m. st. Warszawy. W lutym 1966 r. wymierzył on karę pozbawienia wolności z warunkowym zawieszeniem jej wykonania; wyrok został utrzymany przez sąd drugiej instancji. W październiku 1966 r. minister zwrócił się do Okręgowej Rady Adwokackiej w Łodzi o skreślenie K. Głogowskiego z listy

49 Dekret z dnia 13 czerwca 1946 r. o przestępstwach szczególnie niebezpiecznych w okresie odbudowy Państwa (Dz.U. Nr 30 poz. 192).

50 A. Kern, M. Relisz-Redlicki, Adwokat Karol Głogowski (1933-2005), „Palestra” 2005, nr 1112(575-576), s. 311-312; zob. też: W.J. Muszyński, Niepokorny. Życie i działalność Przemysława Górnego, „Biuletyn Instytutu Pamięci Narodowej” 2006, nr 1-2(60-61), s. 38-40. 
adwokatów na podstawie art. 80 ustawy z 1963 r. ${ }^{51}$ Zgodną z tym żądaniem uchwałę podjęto stosunkiem głosów siedem do sześciu. W sprawie karnej ponownie wypowiedział się Sąd Najwyższy, uchylając wyroki sądów warszawskich obu instancji. W ponownym procesie Głogowskiemu wymierzono karę dziewięciu miesięcy pozbawienia wolności, tym razem bez zawieszenia jej wykonania. Przed odbyciem kary skazanego uchroniła kolejna amnestia ${ }^{52}$.

Karol Głogowski pozostał aktywnym opozycjonistą. W latach 70. podpisał się pod kilkoma protestami kierowanymi do władz PRL (m.in. w sprawie zmiany konstytucji). W styczniu 1981 r. przywrócono mu prawo wykonywania zawodu adwokata, a w stanie wojennym został internowany. W 1983 r. został członkiem Naczelnej Rady Adwokackiej, a sześć lat później bez powodzenia (gdyż bez poparcia Komitetów Obywatelskich „Solidarności”) ubiegał się w Łodzi o wybór do Senatu ${ }^{53}$.

Już podczas zgromadzenia w 1962 r. K. Głogowski wygłosił przemówienie, które stanowiło głos sprzeciwu wobec działań Ministerstwa Sprawiedliwości przygotowującego nową ustawę o ustroju adwokatury. Bezpośrednio po rozpoczęciu obrad zgłosił wniosek formalny o wprowadzenie do porządku obrad punktu dotyczącego wyboru Rady, który powinien nastąpić w 1962 r., a którego nie przewidywano z uwagi na planowane przyjęcie nowej ustawy. Wobec wyraźnego sprzeciwu dziekana Albrechta za wnioskiem padły zaledwie trzy głosy ${ }^{54}$. Zabrawszy głos w dyskusji, adw. Głogowski przekonywał, że choć „cała adwokatura ma być wsłuchana w to, co Pan Minister chce, i każde skinienie, każde życzenie Pana Ministra adwokatura ma brać za dobrą monetę", to minister nie ma racji, dążąc do zmiany ustroju adwokatury, a ona musi tego dowieść. Wskazywał przy tym, że adwokaci „są w stanie podjąć tę problematykę wszakże pod jednym warunkiem. Mianowicie, że Pan Minister nie będzie ograniczał demokracji, że Pan Minister nie zlikwiduje walnego zgromadzenia po to, żeby Głogowskiemu odebrać prawo głosu” ${ }^{55}$. Mówił też, że „nasza istota zawodu wymaga demokracji, że nie da się adwokatem kierować, adwokat musi być wolny”, a adwokatura jest zróżnicowana, także pod względem politycznym, zatem przedstawiciele różnych tendencji muszą mieć prawo głosu ${ }^{56}$. Co ciekawe, zapewne dla uniknięcia zarzutu o szerzenie antyustrojowej propagandy, w swoim wystąpieniu Głogowski odwoływał się do myśli Chruszczowa i materiałów z XXII Zjazdu KPZR ${ }^{57}$.

51 Przepis ten stanowit, że rada adwokacka może skreślić adwokata z listy na skutek wyroku skazującego lub trzykrotnego ukarania dyscyplinarnego za czyny tego samego rodzaju lub za czyny podrywające w poważny sposób zaufanie do obwinionego jako adwokata.

52 A. Kern, M. Relisz-Redlicki, Adwokat..., s. 313-316.

53 Tamże, s. 316-317.

54 Protokót 1962, s. 5-9.

55 Tamże, s. 62, 67.

56 Tamże, s. 61, 69.

57 Tamże, s. 58-60. 
W trakcie zgromadzenia z 1965 r. Andrzej Kern wniósł o umieszczenie w porządku obrad punktu dotyczącego adwokatów zawieszonych w prawie wykonywania zawodu (czyli Karola Głogowskiego). Dziekan Albrecht nie poddał jego wniosku pod głosowanie, gdyż uznał go za zgłoszony w nieprzepisowym terminie ${ }^{58}$. Kern powrócił więc do sprawy w wolnych wnioskach, przedstawiając informację o skierowanym do ministra sprawiedliwości przez 45 członków Izby apelu o uchylenie zawieszenia K. Głogowskiego w prawie wykonywania zawodu. Powołał się na jego trudną sytuację życiową i wniósł o przyznanie zawieszonemu zasiłku w kwocie 3000 zł wypłacanego z Funduszu Wzajemnej Pomocy. Do apelu odniósł się wiceminister Zawadzki:

apel jest wyrazem zorganizowanej walki politycznej, którą podejmuje organizacja, do której należy adw. K. Głogowski. Nie wiadomo, czy ci adwokaci składający podpisy pod niniejszym apelem dobrze wiedzą, jakiego rodzaju materiały przechowywał adw. K. Głogowski.

Wskazał też, że z wnioskiem do ministra mogłaby zwrócić się komisja dyscyplinarna, a nie zgromadzenie Izby. Po wypowiedzi Zawadzkiego przewodniczący obradom adw. Stefan Terlikowski stwierdził, że sprawa została wyczerpana, skoro minister od razu udzielił odpowiedzi ${ }^{59}$.

Rok później na temat sprawy Głogowskiego usiłował wypowiedzieć się adw. Zenon Szczęsny. Przewodniczący obradom Mirosław Olczyk nie dopuścił do przemówień dotyczących tej sprawy, powołując się na zasadę, że dyskutować można tylko o sprawach ujętych w porządku obrad („dobre obyczaje nie pozwalają dyskutować o sprawach zawisłych w Sądach i Komisjach Dyscyplinarnych") ${ }^{60}$.

W 1967 r. sam dziekan Albrecht odniósł się do sprawy Głogowskiego. Jego zdaniem niektórzy adwokaci „,z reguły entuzjastycznie witali jego krasomówstwo, nawet wtedy, gdy było ono obraźliwe dla członków naszej izby, ordynarne i sprzeczne z tradycjami polskiej adwokatury”, a „dookoła tej sprawy zapanowała jakaś psychoza”. Albrecht oświadczył wówczas, że głosował za skreśleniem Głogowskiego z palestry, dzięki czemu „w ten sposób daliśmy dowód podporządkowania się jakimś zasadniczym liniom politycznym”. Tłumaczył przy tym, że Głogowski sam powinien przenieść się na teren innej Izby ${ }^{61}$.

58 Protokót 1965, s. 2.

59 Protokót 1965, s. 13-14. Załącznik do protokołu stanowił apel w sprawie adw. Głogowskiego, w którym wzywano zgromadzenie do wystąpienia z właściwym wnioskiem do ministra (tymczasem zgromadzenie nie zajęło się nawet rozpoznaniem wniosku o podjęcie takiej uchwały). Wskazywano też, że od decyzji ministra zainteresowanemu nie służył żaden środek odwoławczy, co uniemożliwiało mu obronę praw. Przedstawiono także ocenę Karola Głogowskiego, który - zdaniem autorów - „dał się poznać jako człowiek niecodziennego zaangażowania społecznego, nieposzlakowanego charakteru, dużej inteligencji i wielkiej koleżeńskości”. Większość podpisów pod dokumentem była niewyraźna, niewielu - jak Kazimierz Jocz - podpisało się w sposób całkowicie czytelny.

60 Protokót 1966, s. 10.

61 Protokót 1967, s. 15-17. 
W dyskusji prowadzonej podczas tego samego zgromadzenia Karol Głogowski znalazł obrońców. I tak - adw. Tadeusz Szczerbic wskazywał, że nie został on skazany za przestępstwo hańbiące, a przypisany mu czyn dotyczył sprawy ideowo-politycznej i powinien być rozpatrywany na odrębnej płaszczyźnie. Przekonywał też, że skreślenie Głogowskiego może skutkować nieudzieleniem absolutorium Radzie, co oczywiście nie nastąpiło ${ }^{62}$. R. Kowalski twierdził zaś, że usuniętemu koledze wyrządzono krzywdę i nie jest on „adwokatem o antypaństwowym nastawieniu"63. Natomiast Tadeusz Jackowski pozwolił sobie na ocenę działań resortu sprawiedliwości i wskazał, że „organy adwokatury nie powinny reprezentować interesu ministra, lecz interes kolegi. Rada powinna doprowadzić do rozwiązania niż wydać decyzję zgodną z wnioskiem ministra" ${ }^{24}$.

\section{Uwagi końcowe}

Trudno jednoznacznie ocenić przedstawione wyżej dyskusje prowadzone pół wieku temu przez łódzkich adwokatów. Nie ma bowiem wspólnego mianownika dla przywoływanych wystąpień. Część z nich to wypowiedzi formułowane językiem żywcem zaczerpniętym ze szpalt „Trybuny Ludu”, świetnie wpisujące się w gomułkowską rzeczywistość. Adwokaci Jaklicz, Błochowicz i Korczak o znaczeniu partii dla adwokatury i zadaniach socjalistycznej palestry mogliby z powodzeniem opowiadać na szkoleniach Wieczorowego Uniwersytetu Marksizmu-Leninizmu. Podobne nuty pobrzmiewały w wystąpieniach dziekana Albrechta, choć w tym przypadku trudno rozstrzygnąć, $\mathrm{w}$ jakim stopniu wynikało to $\mathrm{z}$ potrzeby serca i poglądów mówcy, a w jakim stanowiło jedynie podporządkowanie się konwencji obowiązującej w ówczesnym życiu publicznym. Zebrany materiał pozwala za to na sformułowanie wniosku, że "głos socjalistycznej adwokatury” nie był w debacie dominujący, stanowił jedynie nieznaczną część dyskusji, a gomułkowska nowomowa nie stała się językiem łódzkiej palestry.

62 Tamże, s. 20-21.

63 Tamże, s. 22.

64 Tamże, s. 24. W piśmie przesłanym później do władz Izby adw. Jackowski przekonywał, że nie mówił ani o interesie ministra, ani o rozwiązaniu się Rady. Jego sprostowanie trudno jednak uznać za wyraz prawomyślności, znajdujemy w nim bowiem fragment, w którym autor mało entuzjastycznie odniósł się do socjalistycznej rzeczywistości. Wyrażając zdziwienie, że protokół nie jest sporządzony na podstawie taśmy magnetofonowej (choć zgromadzenie było nagrywane), pytał: „czyżby zapis na taśmie służyć miał jakimś innym celom, które pozostać mają tajemnicą dla uczestników zgromadzenia?" - [Pismo adw. Tadeusza Jackowskiego z dnia 27 listopada 1967 r.], w teczce: Protokót zgromadzenia [...] 1967. 
$\mathrm{Z}$ drugiej jednak strony równie nieliczne były głosy krytyczne wobec działań władzy ludowej, zaś przemówień poddających negatywnej ocenie ustrój socjalistycznej Polski jako taki - z oczywistych względów - nie było. W zasadzie wszystkie wystąpienia krytyczne związane były z postacią Karola Głogowskiego. Najpierw, w 1962 r., było to obszerne wystąpienie samego Głogowskiego, a w kolejnych latach wypowiedzi jego obrońców, na czele z Andrzejem Kernem przedstawiającym zbiorowy apel do ministra sprawiedliwości (1965 r.). Oświadczenie to $\mathrm{z}$ pewnością stanowiło ewenement $\mathrm{w}$ gomułkowskiej Polsce, śmiało bowiem można uznać je za głos sprzeciwu wobec praktyki ustrojowej PRL. Nie może więc dziwić stanowcza reakcja wiceministra Zawadzkiego, który apel uznał za „wyraz zorganizowanej walki politycznej". Nic jednak nie wskazuje, by podpisani pod petycją adwokaci zostali w jakikolwiek sposób ukarani.

Niezależnie od reakcji Zawadzkiego docenić należy sam fakt przedstawienia apelu podczas zgromadzenia Izby i uznania go za załącznik do protokołu z jego przebiegu. Zapewne na większości ówczesnych zebrań nie doszłoby do takiego aktu niesubordynacji. Uznać zatem możemy, że władza ludowa gotowa była tolerować dość dużą swobodę wypowiedzi adwokatów. Być może dlatego, że wystąpienia miały niezbyt wielu słuchaczy (ok. 100), wywodzących się ze środowiska uznawanego za politycznie niepewne. Nawet jeśli zatem dostrzeżemy, że adwokaci mieli, choć ograniczoną, wolność głoszenia opinii krytycznych wobec działań władzy, to zauważyć również musimy, że była to wolność na wyspie, po pierwsze, niewielkiej, a po drugie, dobrze izolowanej od społeczeństwa.

Zastanawiające wydaje się nastawienie wobec sprawy adw. Głogowskiego prezentowane przez dziekana Zygmunta Albrechta. Zrozumiała jest jego ostrożność i wynikające z niej dążenie do unikania wystąpień, które można byłoby uznać za antysystemowe. Jednak ocena osoby i działań Głogowskiego wygłoszona przezeń w 1967 r. wydaje się wynikiem jego własnych przekonań, zbieżnych z ocenami przedstawicieli władzy, i zdecydowanie wykracza poza granice zachowawczości podyktowanej ochroną interesu adwokatury i jej ograniczonej samorządności.

Uczestnicy zgromadzeń zapewne cenili sobie możliwość prowadzenia rzeczywistej debaty. Trafnie ujął to Bronisław Appel: „konieczna jest atmosfera dla zdrowej krytyki, a nie słuchanie wystąpień konformistycznych"65. Margines tej dopuszczalnej „zdrowej krytyki” inaczej definiowali przedstawiciele władz partyjnych czy dziekan Albrecht, a inaczej Karol Głogowski i jego zwolennicy. Był to jednak margines i tak zdecydowanie szerszy niż w wielu innych dziedzinach ówczesnego życia społecznego. 


\section{Bibliografia}

\section{Akty prawne}

Dekret z dnia 13 czerwca 1946 r. o przestępstwach szczególnie niebezpiecznych w okresie odbudowy Państwa (Dz.U. Nr 30 poz. 192).

Ustawa z dnia 27 czerwca 1950 r. o ustroju adwokatury (Dz.U. Nr 30 poz. 275).

Ustawa z dnia 19 grudnia 1963 r. o ustroju adwokatury (Dz.U. Nr 57 poz. 309).

Regulamin zgromadzeń delegatów w wojewódzkich izbach adwokackich uchwalony przez Naczelna Izbe Adwokacka dnia 29 lutego 1964 r. i zatwierdzony przez Ministra Sprawiedliwości decyzją z dnia 13 marca 1964 r., archiwum Okręgowej Rady Adwokackiej w Łodzi, w teczce: Protokół ze Zgromadzenia Delegatów Łódzkiej Wojewódzkiej Izby Adwokackiej 17 IV 1966 r., sygn. 7/18.

\section{Dokumenty z archiwum Okręgowej Rady Adwokackiej w Łodzi}

Stenogram. Walne Zgromadzenie Adwokackiej Izby Łódzkiej. Łódź, dnia 16 grudnia 1962 r., w teczce: Walne Zgromadzenie Delegatów r. 1962. Mec. W. Osuchowski. Stenogram 1962, sygn. 7/13.

[dwa pisma Okręowej Rady Adwokackiej w Łodzi z dnia 29 kwietnia 1964 r. do Wojewódzkiego oraz Łódzkiego Komitetu Frontu Jedności Narodu], w teczce: Protokół Zebrania Delegatów r. 1965, sygn. 7/16.

Protokół ze Zgromadzenia Delegatów Łódzkiej Izby Adwokackiej odbytego w dniu 11 kwietnia 1965 r. w lokalu własnym przy ul. Piotrkowskiej 63, w teczce: Protokół Zebrania [...] 1965.

Protokót ze Zgromadzenia Delegatów Łódzkiej Wojewódzkiej Izby Adwokackiej odbytego w dniu 17 kwietnia 1966 r. w lokalu własnym przy ul. Piotrkowskiej 63, w teczce: Protokół ze Zgromadzenia [...] 17 IV 1966 r.

[Pismo sekretarza ORA Stefana Majsterka do Naczelnej Rady Adwokackiej z dnia 7 czerwca 1966 r.], w teczce: Protokót ze Zgromadzenia [...] 17 IV 1966 r.

Protokół Zgromadzenia Delegatów Wojewódzkiej Izby Adwokackiej w Łodzi z dnia 16 kwietnia 1967 r., w teczce: Protokót zgromadzenia delegatów Wojewódzkiej Izby Adwokackiej $w$ Łodzi 1967, sygn. 7/21.

[Pismo adw. Tadeusza Jackowskiego z dnia 27 listopada 1967 r.], w teczce: Protokół zgromadzenia [...] 1967.

Sprawozdanie Okręowej Rady Adwokackiej za 1968 r., w teczce: Walne Zgromadzenie Delegatów Wojewódzkiej Izby Adwokackiej w Łodzi w dniu 16 IV 1967, sygn. 7/22.

Protokót Zgromadzenia Delegatów Wojewódzkiej Izby Adwokackiej w Łodzi w dniu 6 IV 1968 r., w teczce: Zgromadzenie Delegatów Izby Adwokackiej w Łodzi w dniu 6 IV 1968, sygn. $7 / 23$.

Sprawozdanie Okręgowej Rady Adwokackiej za 1968 r., w teczce: Walne Zgromadzenie [...] 16 IV 1967. 


\section{Literatura}

60 Lat Łódzkiej Izby Adwokackiej, Okręgowa Rada Adwokacka w Łodzi, Łódź 2009.

Albrecht Z., Przemówienie na Walnym Zgromadzeniu Izby łódzkiej w dniu 19 marca 1961 r. (fragmenty), „Palestra” 1961, nr 5(41).

Kern A., Relisz-Redlicki M., Adwokat Karol Głogowski (1933-2005), „Palestra” 2005, nr 11-12(575-576).

Muszyński W.J., Niepokorny. Życie i działalność Przemysława Górnego, „Biuletyn Instytutu Pamięci Narodowej” 2006, nr 1-2(60-61).

Redzik A., Kotliński T.J., Historia adwokatury, Redakcja „Palestry”, Warszawa 2012.

Zaborski M., Cuius regio, eius palestra? Na drodze do adwokatury państwa totalitarnego. Przemiany ustrojowe adwokatury polskiej w latach 1944-1963, [w:] Cuius regio, eius religio. Publikacja po Zjeździe Historyków Państwa i Prawa, Lublin, wrzesień 2006, t. II, red. G. Górski, L. Ćwikła, M. Lipska, Wydawnictwo Katolickiego Uniwersytetu Lubelskiego, Lublin 2008. 